\title{
Archery Platforms (Vahi te'a) in the Society Islands, Polynesia
}

\section{A contextual interpretation}

\author{
Paul Wallin
}

\begin{abstract}
The aim of this paper is to try to reach a better understanding of the meanings of archery platforms and the rituals which took place around the archery competitions in the Society Islands in central Polynesia. A contextual interpretation of the material remains is therefore suggested. The conclusions based on the archaeological and ethnohistorical descriptions show that the development of archery platforms took place within a specific historical context and expresses the Polynesian concepts of mana (power) and tapu (prohibitions).
\end{abstract}

Paul Wallin, The Kon-Tiki Museum. Institute for Pacific Archaeology and Cultural History, NO-0286 Oslo, Norway.

The Polynesian society has been described as a stratified chiefdom with leading chiefs, lower chiefs, and the common people. Within these groups there were also specialists, such as farmers, fishermen, stone monument constructors, etc. (Sahlins 1958; Renfrew 1973: 170-182). This gives an image of a strong and stable society, but investigations on Hawaii clearly show a different picture. The position of the leading chief was very difficult to maintain, as there was strong competition and pressure from other chiefs, and in many cases also competition from the younger brothers who were possibly the most dangerous rivals (Keesing 1981:191; Davenport 1969; Valeri 1985; Wallin 1993:125pp; Sahlins 1988:103). In this society religious stone structures expressed power (mana) which was transferred from the gods to the chiefs, who thereby became the personified link between the gods and the humans. The gathering places, represented by the ceremonial stone structures (called marae), existed in great number in the Society Islands (see Wallin 1993). In connection with the marae structure and the concept of mana, another important stone structure was the archery platform (Vahi te'a). This kind of structure generally had a more specified function than the marae, even if there are indications that certain marae structures were dedicated to certain specialists. According to ethnohistoric sources, only the leading segments of the society (ari' $i$ and ra'atira) had access to the archery platform. The "noble sport" of archery was prohibited to the common people. Archery was intimately tied to its special god, Patutetavae, and thereby the sport also had a strong religious connection.

The existing archaeological and ethnohistorical descriptions concerning the archery platforms are presented here, and the aim is to view the structures within their social context. The question, why archery platforms, is asked.

To obtain a contextual interpretation I 
suggest that ethnohistorical descriptions ought to be discussed on the basis of knowledge of Polynesian symbolism. The descriptions can thereby be given specific meanings. Such meanings have, for example, been discussed by Hodder (1986). The intention of this paper is furthermore to give an example of how the material culture (here the archery platforms) developed out of the existing ideological concepts - which in this case were controlled through mana (power) and tapu (prohibitions) - within a specific historical context.

\section{THE ARCHAEOLOGICAL RECORD:} ARCHAEOLOGICAL INVESTIGATIONS Because of the lack of good ethnohistorical descriptions of how the archery platforms were constructed, we have to rely on archaeologist Kenneth P. Emory's descriptions of the structures which the native guides told him were archery platforms. Emory was thereby the first to give a detailed description of this kind of stone structure, shown to him in the Papenoo valley on Tahiti (Emory 1933). Later Roger C. Green found and described archery platforms in the Opunohu valley on Mo'orea (1961), and some years later Emory and Yosihiko H. Sinoto described two archery platforms found close to marae Taputapuatea in Opoa on Raiatea (1965). Ellis (1829) also mentions an archery platform on Huahine. This kind of stone structure has thereby been recorded from all the main islands in the Society Islands (fig. 1).

\section{GENERAL MORPHOLOGICAL}

\section{DESCRIPTION OF THE ARCHERY PLATFORMS}

The archery platforms described by Emory (see fig. 2a-c) had a height of about $30 \mathrm{~cm}$ in the back and $60 \mathrm{~cm}$ in the front. The structures have a rectangular shape, and the rear side varies from $4-6 \mathrm{~m}$. The two long sides vary from $6-10 \mathrm{~m}$. The platform increases in width towards the front, and the long sides are also slightly curved close to the front corners. The front is concave, which makes the corners point forward about two meters on each side seen from the centre of the front. On the tip of each arm is a large upright stone slab, but the top of it is level with the surface of the platform. The platform is divided transversely by an unpaved, earth-filled strip, which is sometimes $10-20 \mathrm{~cm}$ below the rest of the platform. The rear part of the structure is about $30 \mathrm{~cm}$ higher than the front part, and paved with large rough stones. The front part of the platform is also divided until about $60 \mathrm{~cm}$ from the front by an unpaved, but earth filled, longitudinal strip about 90-180 $\mathrm{cm}$ wide. This strip is also lowered c. 10-20 $\mathrm{cm}$ in comparison with the surrounding platform, which is paved with flagstones. At the front of the unpaved strip is a flat upright stone slab, which is c. $30 \mathrm{~cm}$ high. The borders of the structures are quite nicely constructed, often made of four layers of stones, and of these layers the first fundamental layer is made of larger stones. The borders of the unpaved strips are marked by stones set on edge. Upright stones also occur at the corners of the rear short side, as well as on the plat form close to one of these corners. The building material consists of basalt stones; no coral stones were found at any of these archery platforms (Emory 1933:43). These structures of the Papenoo Valley have recently been re-investigated and restored by Claudio Cristino (Cristino \& Edwards 1990).

The archery platforms on Mo'orea, described by Green (1961), show mainly the same basic outline as the ones described by Emory. One of them though, is double the size of Emory's largest one. This one also differs in that it is higher in the rear than in the front. Christophe Descantes, who recently reanalysed the field material from the Opunohu valley, writes the following concerning the archery platforms there: "Each archery platform corresponds to a small simple marae in association with the large and complex parental marae. As each household required a simple marae, the two higher-ranked house- 


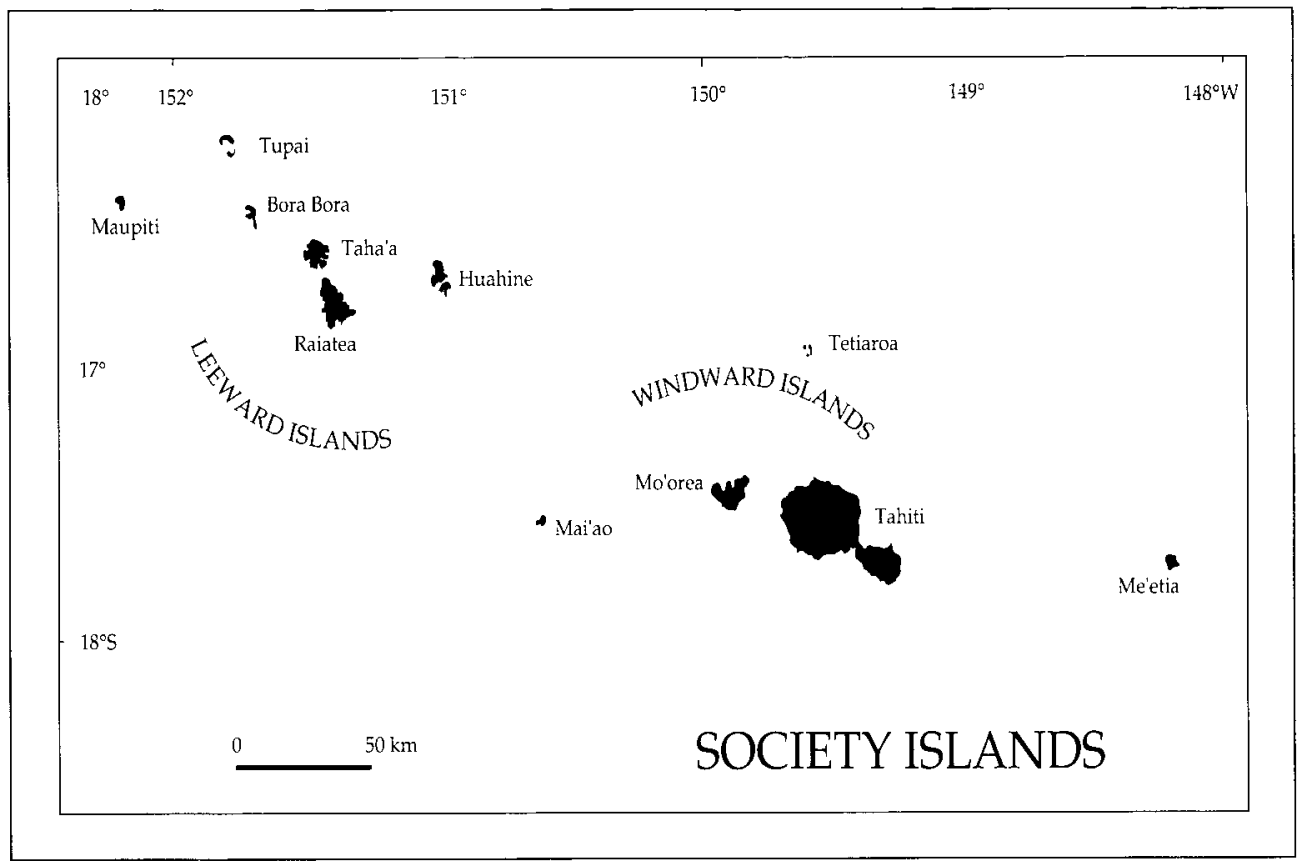

Fig. 1. Map of the Society Islands. (After Wallin 1993:21).

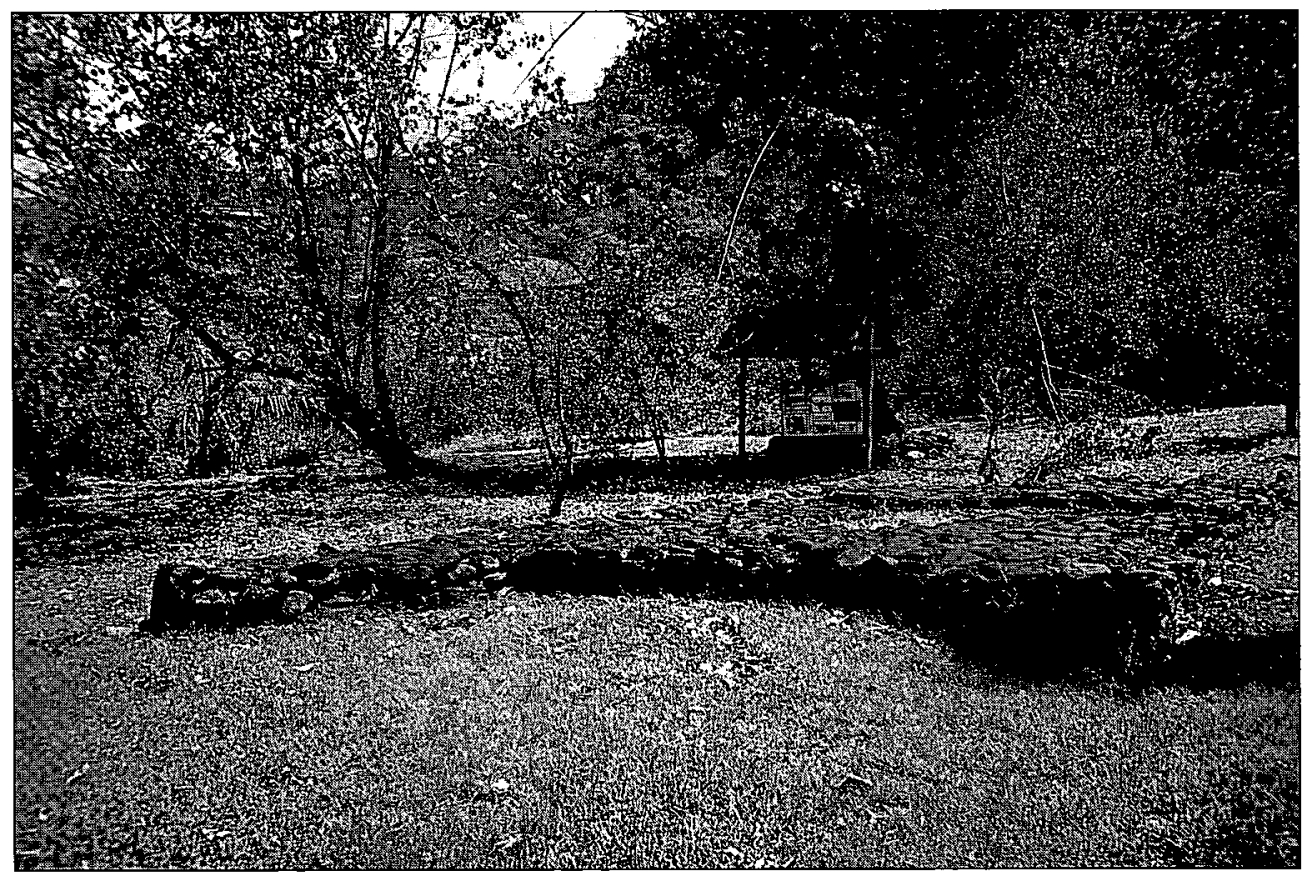

Fig. 2a. Archery platform at Vaihi, Tahiti. Emory's site 70 (1933). Photo: P. Wallin. 


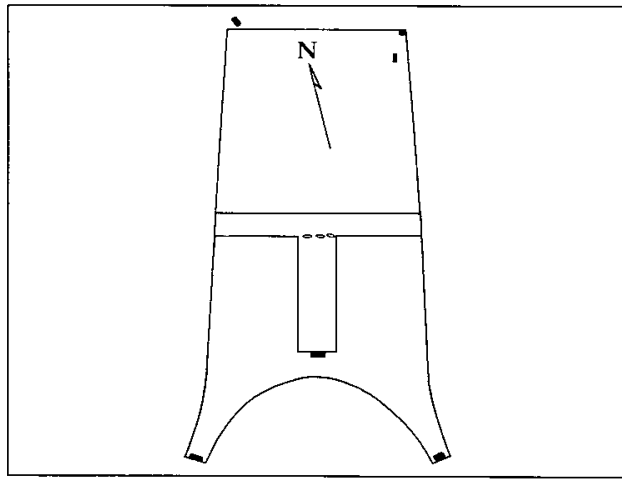

Fig. 2b. Plan drawing of archery platform at Vaihi, Tahiti. (After Emory 1933:89, site 70).

holds of marae 0-161b also commanded their respective archery platform" (Descantes 1993: 206). He also mentions that there is one other archery platform in the Opunohu valley, and this shows the same connection to a marae of the same type as the one above, with one connected simple marae.
The archery platforms from Opoa on Raiatea, described by Emory and Sinoto (1965), also have larger dimensions than the ones from Tahiti. The largest is c. $18 \times 9 \mathrm{~m}$ and about $70-80 \mathrm{~cm}$ high. The platform is paved with flat stones, but shows no signs of divisions (1965:65).

\section{THE CHRONOLOGICAL POSITION OF} THE ARCHERY PLATFORMS

Only one ${ }^{14} \mathrm{C}$ dating has been made in connection to an archery platform. This charcoal sample collected by Emory and Sinoto was found at a depth of $70 \mathrm{~cm}$ under the present surface, at one of two archery platforms close to marae Taputapuatea. The sample (Gak403) gives a calibrated dating to A.D. 14801661 (Wallin 1993:68). Emory and Sinoto write the following: "This would indicate that archery platform No. 1 was built later than the 16th century A.D.; but that the stone platform could have been built not long after this date" (1965:66). It has later been shown that early datings made by the Gak (Gaku-

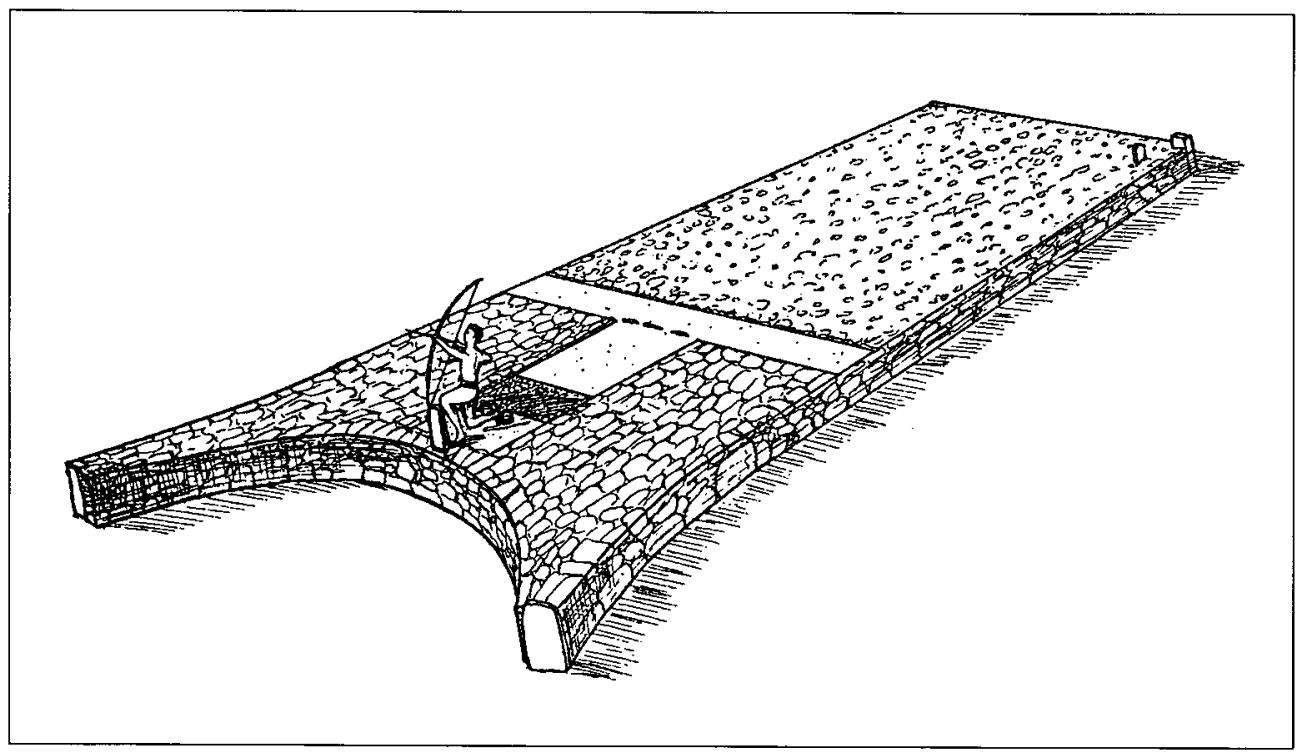

Fig. 2c. Reconstruction of archery platform at Vaihi, Tahiti. (After Emory 1933:43, site 70). 
shuin) laboratory may suffer from certain technical problems. This dating should therefore simply be seen as an indication, and it is still the only one existing.

\section{THE ETHNOHISTORICAL RECORD: THE EQUIPMENT AND THE COMPETITOR}

The bow was about $150 \mathrm{~cm}$ long, nicely polished and sometimes decorated with braided human hair or cocoanut fibres applied as rings at both ends of the bow. The arrows were made of bamboo, c. $70-90 \mathrm{~cm}$ long and with an unbarbed point of iron-wood. The quiver was nicely decorated with human hair and, as a lock on top of it there was a polished cocoanut shell (Ellis 1829:299-301).

Archery was a sport dedicated to the chiefly segments of the society (called ari' $i$ and ra'atira) (Moerenhout 1837:148; Handy 1930: 58; Emory 1933:41). Te' a (archery) was thereby seen as a "holy" sport, which the missionary William Ellis describes as "usually practised as a most honourable recreation, between the residents of a place and their guests" (Ellis 1829:299). But it is likely that it was not the leading chiefs themselves that were the competitors, but other representative ari' $i$ relatives. Ellis mentions "the king and the chiefs usually attending to witness the exercise" (Ellis 1829:301; Henry 1928: 279), but on the other hand, the Spaniard Varela mentions that the chiefs from different districts gathered for an archery competition (Corney 1915:268). At the competition the archer was dressed in a holy dress called puhipuhi-te'a (to blow or fan an arrow). This dress was kept in a specific house at the marae (Ellis 1829:299; Henry 1928:276; Emory 1933:42).

\section{THE ARCHERY PLATFORM AND ITS POSITION IN THE LANDSCAPE}

Ellis gives a rough description of an archery platform which he had in his garden on the island of Huahine. He says it consisted of a triangular platform, about $90-120 \mathrm{~cm}$ high, and that one side was slightly convex (Ellis 1829:219). Varela and Moerenhout mention that the archer stepped up on a stone platform to shoot his arrows (Corney 1915:268; Moerenhout 1837:148).

According to Ellis, the platforms sometimes were situated close to the base of a mountain or at the beach (Ellis 1829). It is also shown that the selected place was situated on sacred land (Moerenhout 1837:148). Henry further mentions that "The te'a grounds were nicely kept lawns on public property. The site that was set apart for that purpose at Papaoa was whence now stands the Roman catholic church and extending further on the land now under cultivation" (Henry 1928:276). It is a common feature that Christian churches were placed on or close to ground that already had some religious significance for the natives (fig. 3 ).

\section{CEREMONIES AND COMPETITION}

Before the competition the archers went to a marae to undertake certain "purifying" ceremonies in honour of their god, Patutetavae. At the marae they also put on special clothes and picked up their equipment.

After the competition they undressed and gave the dress and equipment to a specific guardian who placed it in the house at the marae. The competitors then washed their bodies carefully before they could do anything else (Henry 1928:276; Emory 1933:42). The party that lost the competition was also supposed to supply the other competitors with a great feast with dancing (Ferdon 1981: 128).

During the competition it was prohibited to light any fire. Varela mentions that: "I remarked that no fires were lighted in any of the houses until some time after the conclusion of the sport; I knew this from some of our people who, finding nothing to light their cigars with, learned through the medium of the interpreter that it is prohibited on these occasions" (Corney 1915:268-269).

The aim of the archery game was to shoot 
the arrow as far as possible. The competitors were thereby not shooting at any special target. A shooting sector was probably outlined by two white flags (Ellis 1829:299). The length of the shot, which was often about 250-300 m, was estimated by several men (three to twelve in number) with small white flags in their hands. When someone in one of the competing groups made a longer shot than anyone from the other group they waved with their flags, but if the shot was shorter the flags were held down and they lifted their foot and shouted "ua pau" (beaten) (Henry 1928:276; Emory 1933:42). Varela mentions that observers also were placed in the highest trees. Possibly they also estimated the height of the shot (Corney 1915:268). That they also were shooting high, is indicated by Varela's description that when they drew their bow they held it almost vertically upwards (Corney 1915:268).

Thus when the archer was supposed to shoot he went up on the Vahi te'a platform, positioned himself with one knee on the ground of the platform, and drew the bow as much as he could, releasing his arrow to the accompaniment of the sound of drums (Ferdon 1981:128). A great output of his strength was thereby shown, and the exhibition of strength and power was probably the main purpose of the competition (Emory 1933:42).

Varela mentioned that at least 50 arrows were shot the morning he watched a competition (Corney 1915:268), and Handy writes that each competitor had ten to twelve arrows in his quiver (Handy 1930:58).

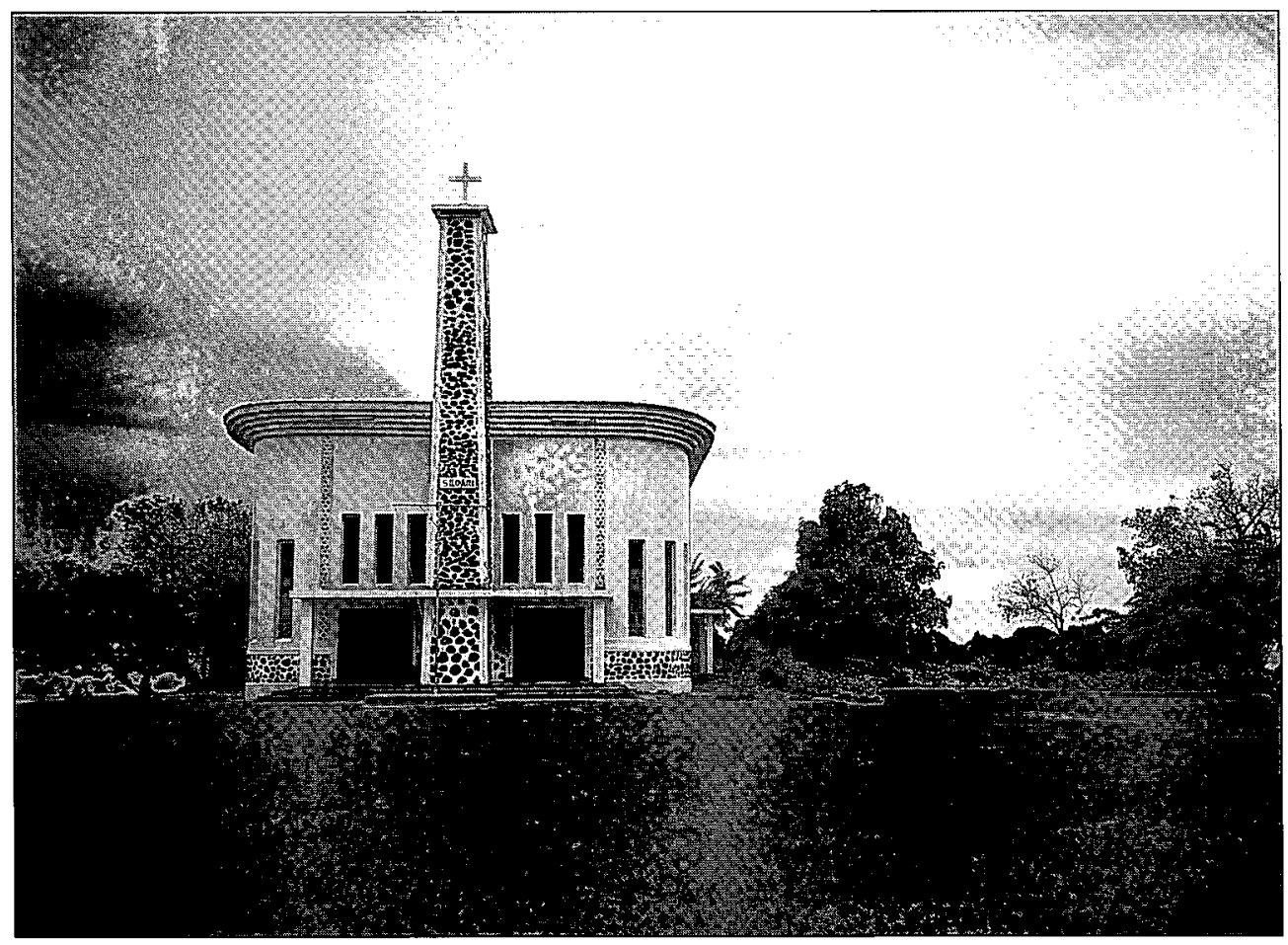

Fig. 3. Christian church placed on the courtyard of marae Tainuu at Tevaitoa, Raiatea Photo: P. Wallin. 
THE BOW'S POSITION AS A WEAPON IN THE SOCIETY ISLANDS AND IN POLYNESIA

The bow and arrow was probably not used as a weapon in times of war in the Society Islands; it was at least never seen in such situations by the early observers. Apparently it mainly was used for ceremonial purposes, although there are descriptions that the bow and arrow occasionally was used for hunting birds on the peninsula of Tahiti (Ferdon 1981:128). Varela noted that the competitors dropped the bow when the arrow was fired, and he says: "if they did not do so; the recoil of the string would cut the hand grasping the bow and it would be a difficult matter to recover it" (Corney 1915:269), which indicates that the bow never could have been used effectively in a war situation.

On other islands in the Pacific there are indications of both peaceful and violent use of the bow and arrow. In the Hawaiian Islands archery was also for amusement, especially for shooting rats (Ellis 1829:302). In Samoa the bow and arrow was used to shoot fish and birds, especially pigeons. The pigeon hunt was also a chiefly sport (Buck 1930:439 $\& 530$; Herdrich 1991). In the Tonga Islands the bow was used both at festivities and in war (Ellis 1829:302). It was also probably

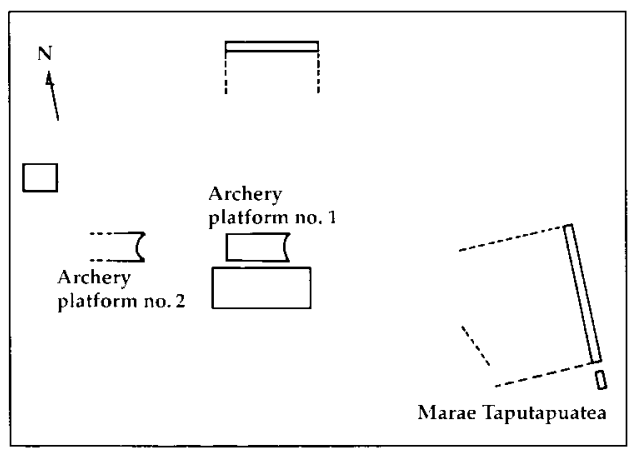

Fig. 4. Archery platforms infront of Marae Taputapuatea at Opoa, Raiatea. (After Emory \& Sinoto 1965). used as a weapon in warfare on the island of Mangareva, to the east of Tahiti (Buck 1938: 193). On Fiji and in Melanesia, the bow and arrow was used as a general weapon in war (Ellis 1829:302; Ferdon 1981:129).

Emory mentions, when he describes the archery platform at Vaihi (Tahiti), that he was told that "It was here a famous warrior, Maneu, drew his bow, and my guides were under the impression that his arrows were directed at enemy forces coming up the valley" (Emory 1933:42). This would possibly indicate that the bow and arrow could have been used in war at some earlier time, before it came under regulated ceremonial forms (Handy 1930:59).

\section{THE ARCHERY PLATFORM IN ITS SOCIAL CONTEXT}

The religious stone structures in Polynesia were mainly a place of control and regulation. Furthermore they were the central point of human communication with the gods. This necessary contact with the spiritual world was mainly controlled by the ari $i$ chiefs. Only the leading chiefs were able to control the most powerful gods. To obtain the power (mana) from the gods, one also had the responsibility to give the proper gifts to them. This relationship also gave the rights, and probably also the sympathy of the people, to the chiefs, who were "forced" to control the efforts and the production. This control was made possible by the many tapu regulations (Wallin 1993).

The archaeological descriptions of the archery platforms show great conformity in their outline. The shape of the structures was clearly defined in the minds of the Polynesians using it. Perhaps the curved front symbolised the bow, and at the same time outlined the shooting sector. The size of the structure, and variations concerning upright stones, may indicate the status of the person in charge of the platform. When giving the archery religious/ceremonial status, only higher-ranked persons had the right to use the 
bows and arrows. Thereby it was possible to legitimise a tapu over the bow as a weapon. The high chiefs thus had the control over a weapon that could be quite dangerous. Used by the wrong persons at a wrong time, the bow and arrow could be seen as a threat against the leading chiefs. There is also an indication that the use of fire was tapu during the archery competitions. Perhaps this tapu was created to prevent this weapon from becoming even more dangerous. Fire arrows, which may have been seen as the ultimate weapon at that time, were thereby under chiefly control.

The early descriptions also mention that the loser of the competition had to give a great feast with dancing. This was probably a way to balance the effect of the defeat. The feast may be seen as the gift of rivalry. The loser was given a second chance to show his power and thereby recover the loss of mana. The stability between the competing parts was by means of this re-established. The defeat in archery could possibly also be changed into a victory, if the feast became a success (cf. Bataille 1991:99 pp).

Concerning the chronological aspects of the archery platforms, there are indications that they developed in a quite late phase, possibly around A.D. 1400-1600. At that time

\section{REFERENCES}

Bataille, G. 1991. Den fördömda delen. Stockholm/Stehag.

Buck, P. 1930. Samoan Material Culture. Bernice P. Bishop Museum Bulletin 75. Honolulu.

- 1938. Ethnology of Mangareva. Bernice P. Bishop Museum Bulletin 157. Honolulu.

Corney, B. G. 1915. The Journal of Don José de Andia y Varela 1774-5. In: The quest and occupation of Tahiti by emissaries of Spain. The Hakluyt Society. Vol. II. London.

Cristino, C. \& Edwards, E. 1990. Archaeological survey of the upper Papeno'o Valley of Tahiti, the war god "Oro" became the most important god in the Society Islands, and the marae concept changed into more elaborate structures that welcomed human sacrifices (Wallin 1993; Garanger 1979; Green et al 1967; Emory 1933). It is suggested that the archery platforms may be seen in this context. The fact that there existed two archery platforms close to the "original" marae of the Oro cult, namely marae Taputapuatea on the island of Raiatea, could indicate a connection between archery and the Oro cult (fig. 4). The human hair used as applications on the bow and quiver gave the equipment strength according to Polynesian beliefs (Handy 1927:268). This hair could probably have been collected from human offerings given to Oro, as such signs increased the status of the game and gave the archer mana.

At a time when the war god became the most important god, it may have been important for the chiefs to obtain control over this weapon, at the same time as it enabled the chiefs to demonstrate and compare their mana in relation to each other in a controlled way. It is suggested that this "sport" thereby prevented and limited what we call "real" warring actions.

English revised by Laura Wrang.

French Polynesia. July 1987- May 1989. Part I. Unpublished working copy. Musee de Tahiti. Papeete.

Davenport, W. 1969. The Hawaiian Cultural Revolution: Some Political and Economic Considerations. American Anthropologist 71.

Descantes, C. 1993. Simple Marae of the 'Opunohu Valley, Mo'orea, Society Islands, French Polynesia. The Journal of the Polynesian Society. Vol. 102.

Ellis, W. 1829. Polynesian Researches. Vol II. London. 
Emory, K. P. 1933. Stone Remains in the Society Islands. Bernice P. Bishop Museum Bulletin 116. Honolulu.

Emory, K. P. \& Sinoto Y. H. 1965. Preliminary Report on the Archaeological Investigations in Polynesia. Field Work in the Society and Tuamotu Islands, French Polynesia and American Samoa 1962, 1963, 1964. Unpublished Manuscript Bernice P. Bishop Museum. Honolulu.

Ferdon, E. N. 1981. Early Tahiti as the Explorers Saw It; 1767-1797. Tucson.

Garanger, J. 1979. Sacred Stones and Rites. Société des Oceanistes. Dossier 2. Paris.

Green, R.C. 1961. La plate forme d'archer et le marae de AFAREAITO, Opunohu Moorea. Bulletin de la Société des Études Océaniennes. Nos 136/137. Papeete.

Green, R.C. et. al. 1967. Archaeology on the Island of Mo'orea, French Polynesia. Anthropological Papers of the American Museum of Natural History. 51 (2). New York.

Handy, E. S. C. 1927. Polynesian Religion. Bernice P. Bishop Museum Bulletin 34. Honolulu.

- 1930. History and Culture in the Society Islands. Bernice P. Bishop Museum Bulletin 79. Honolulu.
Henry, T. 1928. Ancient Tahiti. Bernice P. Bishop Museum Bulletin 48. Honolulu.

Herdrich, D. J. 1991. Towards an Understanding of Samoan Star Mounds. The Journal of the Polynesian Society. Vol. 100.

Hodder, I. 1986. Reading the Past. Current approaches to interpretation in archaeology. Cambridge Univ. Press. Cambridge.

Keesing, R. M. 1981. Cultural Anthropology. A Contemporary Perspective. (Second ed.). New York.

Moerenhout, J. A. 1837. Voyage aux iles de grand ocean. Paris.

Renfrew, C. 1973. Before Civilization. The Radiocarbon Revolution and Prehistoric Europe. Suffolk.

Sahlins, M. D. 1958. Social Stratification in Polynesia. Univ. of Washington Press. Seattle.

- 1988. Kapten Cooks död. Södertälje.

Valeri, V. 1985. Kingship and Sacrifice. Ritual and Society in Ancient Hawaii. Chicago Univ. Press. Chicago.

Wallin, P. 1993. Ceremonial Stone Structures. The Archaeology and Ethnohistory of the Marae Complex in the Society Islands, French Polynesia. AUN 18. Uppsala. 
